\title{
I Prefer My Own Ways to Acquire My English Speaking Skills: A Grounded Research
}

\author{
Fernandes Arung ${ }^{1}$, Zainal Rafli ${ }^{2} \&$ Ratna Dewanti ${ }^{3}$ \\ ${ }^{1}$ Teacher and Education Faculty, Universitas Sembilanbelas November Kolaka, Southeast Sulawesi, Indonesia \\ ${ }^{2}$ Language Education, Graduate Program, Universitas Negeri Jakarta, East Jakarta, Indonesia \\ ${ }^{3}$ English Education, Universitas Negeri Jakarta, East Jakarta, Indonesia \\ Correspondence: Fernandes Arung, Teacher and Education Faculty, Universitas Sembilanbelas November Kolaka, \\ Indonesia. E-mail: fedyarg@gmail.com
}

Received: October 10, 2019

Accepted: November 5, 2019

Online Published: November 13, 2019

doi:10.5430/ijhe.v9n1p32

URL: https://doi.org/10.5430/ijhe.v9n1p32

\begin{abstract}
Formal educational practitioners tend to neglect the students' sense of liking; we labeled as Preferent learning theory, in order to acquire certain skills in the learning foreign language, especially speaking skills. In general, so far, issues of formal learning with the focus on bounded academic rules, cognition, and motivation have been used as the main basis for the learning foreign language and even learning in general. The individual learning, language community, social change, and sophisticated technology need to be considered in how students acquire the skills they want based on their preferences. By investigating how the University students in Kolaka learned and improved their English speaking skills, we applied a Grounded study that involved 10 informants who were the students and alumni of the English Language Education Study Program of the University X in Kolaka, Southeast Sulawesi, Indonesia. All data were collected 12 times in 3 stages and then were analyzed using three steps of Strauss and Corbin's analysis that applied theoretical sampling and constant comparison in generating the substantive theory. The findings revealed that the informants acquired the English speaking skills because of a sense of liking or preference toward any topic to learn. Further, they prefer to learn in unpredictable ways without any rules and an informal self-evaluation that was applied as a way of sustaining the skills.
\end{abstract}

Keywords: foreign language learning, grounded theory, preferent learning, unpredictable learning, informal self-evaluation, speaking skills

\section{Introduction}

The Industry 4.0 was developed in 2011 which Cyber-Physical Systems (CPS) or smart machines dominate human activities where 'machines will redefine themselves in the way they communicate and perform individual functions' (Muhuri, Shukla, \& Abraham, 2019) 'by connecting people, machines, and products by forming a joint production system, which enables faster and more targeted information exchange' (Rauch, Linder, \& Dallasega, 2019), 'demands a socio-technical evolution of the human role in production systems' (Frank, Dalenogare, \& Ayala, 2019). In this condition, Japan began to introduce the industrial 5.0 era in 2015 which further embodied humanitarian functions, 'collaborating humans and smart systems through highly accurate industrial automation supported by critical thinking skills' (Haleem \& Javaid, 2018) and 'more on the essence of human existence, physical integrity, and relations with nature' (Sachsenmeier, 2016). However, for both eras, the need for mastery of foreign language skills is increasingly needed, especially the skills of communication and collaboration to play a role in both eras.

Considering these two industrial eras, the academic world still provides foreign language learning intending to provide opportunities for students to continue to master foreign languages, specifically speaking skills. On the other hand, the activities of non-academic people concern themselves with mastering speaking skills in a more free way without being bound by formal academic rules by utilizing the media on the internet as one of the industrial revolution given (Internet of Thing). The fact is that the mastery of speaking skills seems clear in its achievements to those who are more free in learning it. Why formal learning that has been memorable does not provide opportunities for the students' preference (Enkin \& Correa, 2018; and Funk, 2012) especially learning speaking skills as a foreign language? Must learning prioritize its focus on formal situations and conditions so that the students' learning preferences are limited? In fact, in general, the situation and conditions of informal learning, specifically in 
universities, actually seem more promising to improve skills (Meredith, Fortner, \& Mullins, 1997; Folkestad, 2006; and Rienties \& Kinchin, 2014). Can formal learning mediate students' preferences in learning so that the skills achievement can be realized? (Crawley \& Shrum, 1997; Bolhuis \& Voeten, 2004; Conti, 2009; Chuang, 2012; Haworth, McGee, \& MacIntyre, 2015; and Hu, Gao, Wofford, \& Violato, 2017) Of course, everything depends on how stakeholders think of the right work framework to mediate the students' learning preferences even in the atmosphere of formal learning.

Ideal learning, generally, requires the fulfillment of pre-determined learning outcomes. The learning certainly has great expectations to achieve the required mastery. In learning foreign languages, in this case, English, it appears that the learning objectives set are still merely administrative (Lasagabaster, 2011; Ahmadianzadeh, Seifoori, \& Tamjid, 2018; Ashton, 2017; Liyanage, Bartlett, Walker, \& Guo, 2014; Met \& Byram, 1999; Astika, 2014; and Widiastuti, 2018). In other words, learning achievement is only descriptive in every learning plan and only part of the domain is visible, for example, the mastery of the psychomotor domain is still very minimal compared to other domains, it is more likely to cognition domain. Motivation, as one of the affective domains, is more dominant to be the basis for the success of foreign language learning, both for teachers and students (Arthur \& Beaton, 2007; Kiziltepe, 2008; Brumen, 2011; Ruesch, Bown, \& Dewey, 2012; Yang, 2017; Gearing \& Roger, 2018; and Karimi \& Zade, 2018; etc.), in fact, the motivation is not enough to mediate the foreign language speaking skills.

In the context of EFL, especially in Kolaka district, Southeast Sulawesi where the four local tribes with its vernaculars inhabit the area, the English is not a prestigious language among the tribes' community because they have Bahasa Indonesia and their vernaculars to communicate in the daily life. As a consequence, the university students in the English Language Study Program have to be struggling to show their skills in English speaking. Here is the uniqueness of how they can show their speaking skills in English in such communities. In connection with this, we investigated and grounded a concept about how university students in Kolaka district learned and improved their English speaking skills. Therefore, through this research, we applied the Grounded Theory design in an effort of finding a new substantive theory in the hope of being a consideration, both for learners and teachers of foreign languages, specifically for foreign language learners in the universities that refer to the same characteristics of the mentioned communities.

\section{Methodology}

This Grounded research was conducted at the University X in Kolaka district, Southeast Sulawesi, Indonesia. The process of data collection was carried out in three (3) stages and in-depth interview sessions were conducted at each stage, while Focus Group Discussion (FGD) was conducted to provide more specific data on the focus of the research. After doing the data analysis process in the first step; Describing, we produced several concepts and then these concepts were categorized through the second step of the data analysis process called Conceptual ordering. Likewise the second and third stages of data collection and its analysis to the Theorizing process (Strauss \& Corbin, 1998). These stages were conducted based on the Theoretical sampling proposed by Glaser \& Strauss (1999) which is the process that is carried out simultaneously in terms of collecting data, coding, and analyzing the data collected and deciding what type of data will be collected next and where it will be found.

In doing the first stage of data collection, we analyzed transcripts of three interviews and described the data in the form of objects, people, situations and conditions, events, actions, emotions, moods, and aspirations that produced 29 concepts. This first step of the analysis was called Describing. The concepts were analyzed using Constant comparison technique to classify those concepts into categories as the second step of data analysis; Conceptual ordering. We had 10 categories that became our next focus in collecting the data to the second stage. The next, we made some Memos to describe the overall situations and conditions for each process of analysis. We made 61 memos to the end of our study. The last, we compiled and gave a specific code for the first phase of the categorization data.

In the second stage of data collection, we analyzed transcripts of four interviews by doing the first and the second step of the analysis technique (Describing and Conceptual ordering). In this stage, we produced 14 concepts and 5 categories. The next was to determine the next focus in collecting the data, making memos, and giving specific code for the second phase of the categorization data.

In the third stage of the data collection, we analyzed the interview transcript and the results of the FGD in the third step of data analysis called Theorizing for the initial substantive theory. In this step, we did the process of Constant comparison that aimed to crystallize the categories with its properties into the core category and its properties as the crystalized substantive theory. The next was to make memos and propose the hypotheses. 


\section{Results}

\subsection{The First Stage Findings}

Initial data collection was carried out three times against three (3) informants, namely informants I, II, and III. Data collection at this stage aimed to identify how informants learn English speaking skills. After we did the data analysis, which was called the first stage, 29 concepts and 10 categories appeared. The concept arose when the Describing or Open coding data analysis stage was carried out, while the categories appeared after conducting Conceptual ordering or Axial coding. The Describing stage aimed to see and let new ideas emerge. During the Describing process, the interview data were coded on line by line transcripts that usually contained active verbs or a phrase or sentence. Furthermore, all the codes are separated or compared based on the same meaning and then put into abstractions related to the meaning of the units of the codes so that the abstractions become concepts as shown in Figure 1.

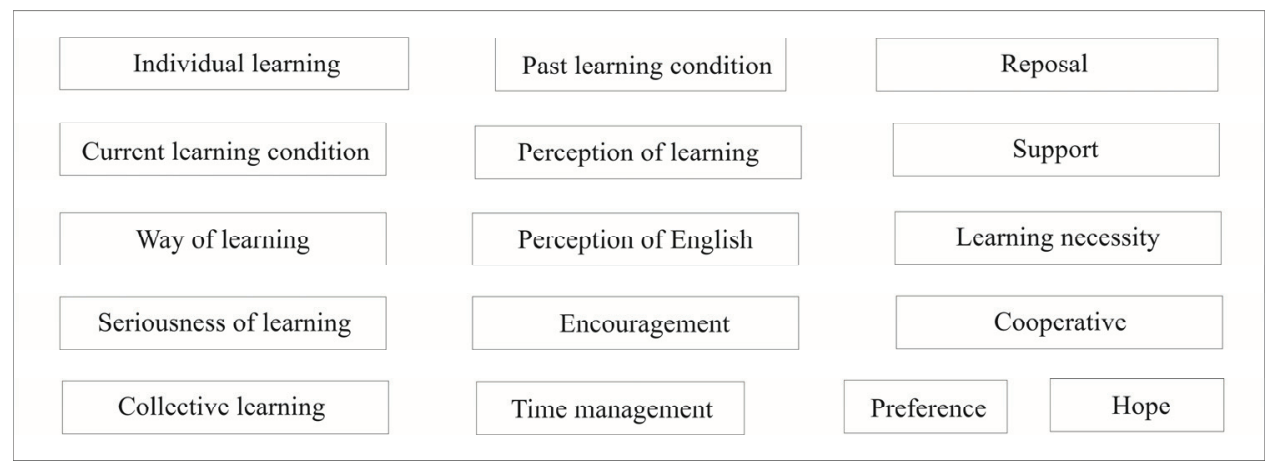

Figure 1. Concepts of the first stage

very time we did an analysis, we also used Memo as a data collection technique. Based on this, we made the Memo in question after naming the concept for the existing codes labeled. Steps like this were carried out consistently for each informant until the 29th concept. Figure 1 below shows the number of concepts in question. These concepts are born from coding units against the data from three interviews. Those concepts are carried out in a Constant comparison process to bring up more abstract categories. At this stage, the second step analysis, Conceptual ordering is done. Through this stage of analysis, we saw that the average category that existed referred to several learning elements so we chose to create categories that referred to the learning elements in question as well as being a further sub-focus for the next collection stage. The categories in the first stage were used as sub-focus for subsequent data collection through semi-structured interviews. So, in the first stage, it only reached the first and second steps of analysis; Describing and Conceptual ordering. The categories were ordered as shown in Figure 2 below as an example.

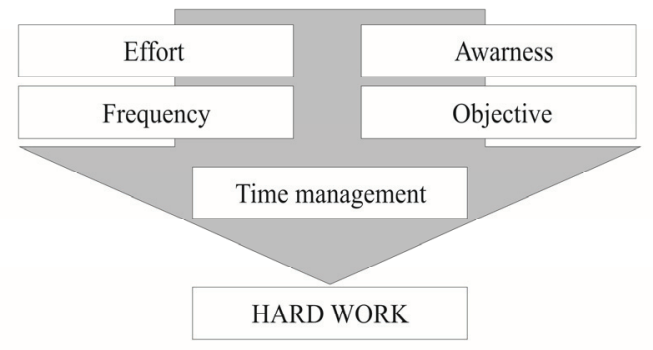

Figure 2. Example of categorization of the first stage

\subsection{The Second Stage Findings}

Before conducting the second stage of data collection, we compiled and gave a specific code for the first stage of the data categorization. We code \#I, \# 2, \# 3, \# 4, \# 5, and so on. For example, Code 46 \# I - 48 \# I, which means the result of interviewing I (first) informant for the code number 46 to 48 . Table 4 shows the meaning of the code in question. Code 54 \# II - 62 \# II, which means the interview results of informant II (second) to code data numbers 54 to 62 .

In the second phase of data collection, we conducted in-depth interviews in four (4) times with four informants, namely informants IV-1, V, VI, and VII. The interview started with the first informant, then the second, and so forth to the seventh informant. This interview focused on ten sub-focuses that refer to learning elements. After collecting 
data for each informant, we carried out a data analysis process with the same steps as the previous analysis in the first stage, namely Describing and Conceptual ordering. Only, in the second stage of data collection, the data analysis process was continued in the third step, Theorizing, where this step produced a substantive theory. These code units in this second stage were abstracted into concepts and we made memos. These steps were carried out on the data of the interview results for each informant so as to produce 14 concepts and 5 categories as shown in Figure 3

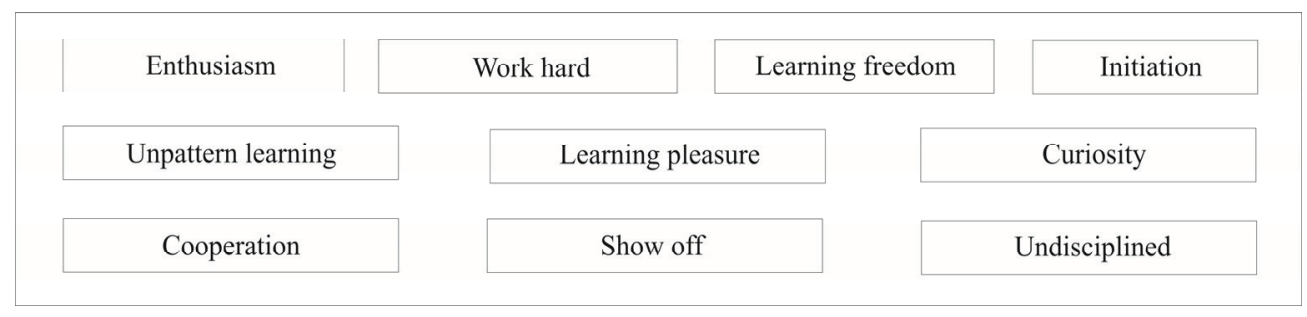

Figure 3. Example of concepts of second stage

After coding units grouped into concept abstractions, then, we did the categorization process through the second step analysis, Conceptual ordering or Axial coding to bring the categories along with their properties. After the categorization process, five initial categories appeared and we ordered as shown in Figure 4 below.

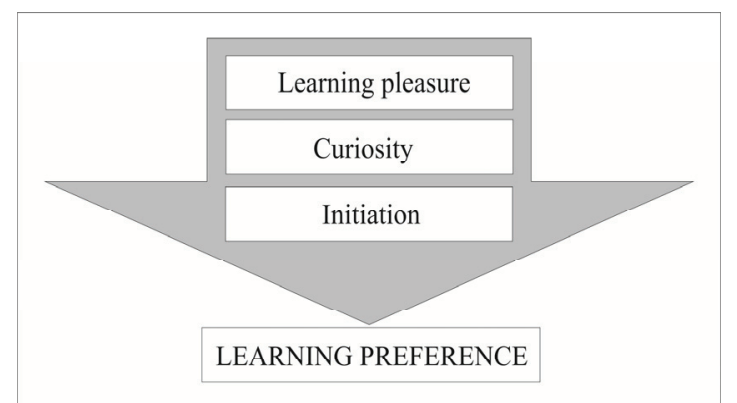

Figure 4. Example of Initial categorization of second stage concepts

Next, we gave a specific code that referred to the data contained in each category. For example, code 36 \# IV - 52 \# IV, which means the interview results of the informant IV (fourth) for the data number code 36 to 52 . These categories appeared through the process of data analysis by applying Constant comparison. These steps were continued in the same way up to the fifth category.

\subsection{The Third Stage Findings}

The focus of this study is the Learning of Speaking Skills in English and the properties of this category are learning preferences, learning patterns, self-evaluation, attitudes, and behavior. Figure 5 below shows what is meant.

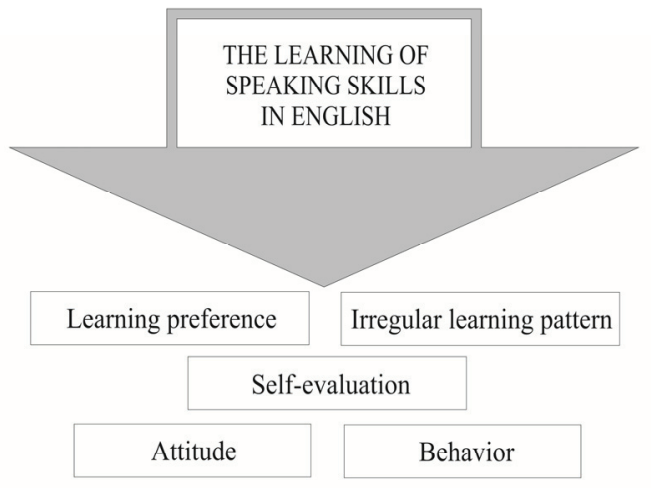

Figure 5. Initial grounded theory 
The learning of English speaking skills of the informants is influenced by preferences; choice by liking, irregular or free learning patterns, attitude, and behavior towards English, as well as the application of self-evaluation which tends to be informal and based on certain goals.

After determining the categories, we then carried out the final step of the analysis, namely Theorizing, which according to Strauss \& Corbin as a way to integrate or unify several categories that have been linked to sub-categories and crystallize these categories into a new theory. At this stage, we re-interviewed informant IV-2 regarding irregular learning or in accordance with their desires. Furthermore, the interview data were analyzed with the same steps as before to crystallize the initial categories and their properties so that the construction of the theory is more apparent. The theoretical process was carried out by analyzing the interview transcripts and the results of the Focus Group Discussion (FGD) and we still made memos. In this session, we show how the initial main categories changed. Figure 6 below explains what is meant.

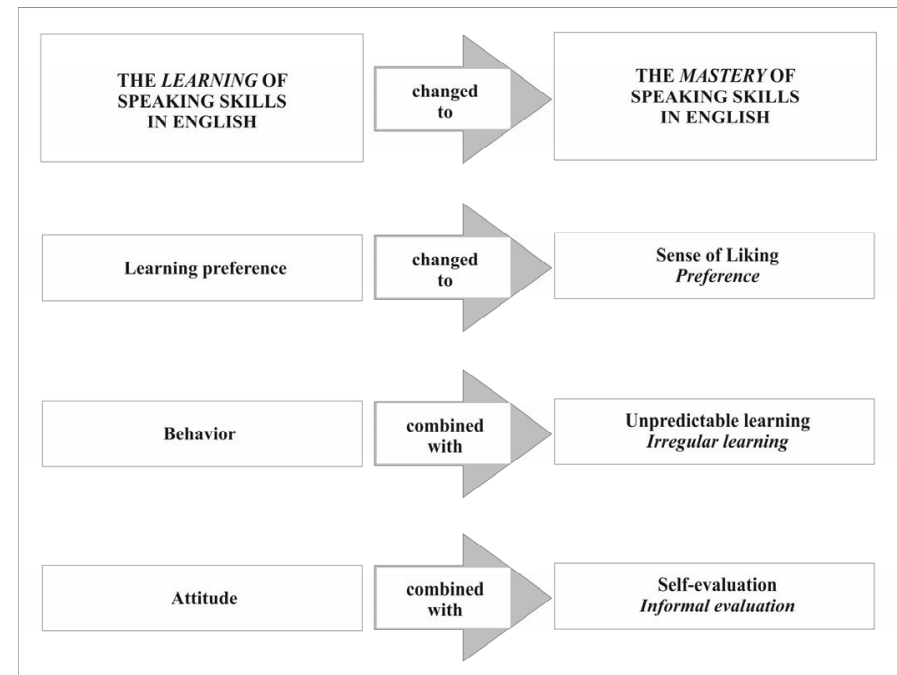

Figure 6. Initial Grounded theory changed in the third stage

Based on the Theorizing process, the initial categories changed and form a more focused structure. The Learning of English Speaking Skills which is the focus of research turns into the Mastery of English Speaking Skills because the three existing properties are fundamental factors for mastering English speaking skills. Learning is a medium for achieving mastery. Learning pleasure changed to Sense of Liking (preference) because it is one indicator of pleasure. The category of Behavior is combined with the category of Unpredictable learning because behavior is part of one's learning pattern. The category of Attitude is combined with the category of Self-evaluation because attitude is a mental revelation of an idea, value, and system that is organized and visible through experiences. Ideas, values, and systems are part of the evaluation processes. A more focused structure can be seen in Figure 7 below.

\begin{tabular}{|c|c|}
\hline Scnsc of liking & Unpredictable lcarning \\
\hline Interactive correlation & Interactive correlation \\
\hline \begin{tabular}{c} 
THE MASTERY OF \\
ENGLISH \\
SPFAKING SKILL \\
Causal correlation \\
\hline Self-evaluation \\
\hline
\end{tabular} \\
\hline
\end{tabular}

Figure 7 . The core substantive theory 
Explanation:

- The Mastery of English Speaking Skill: Main category; Research focus.

- Sense of Liking (preference): sub-category; sub-focus of research.

- Unpredictable learning (free-will learning): sub-category; sub-focus of research.

- Self-evaluation (informal evaluation): sub-category; sub-focus of research.

Based on the substantive theory, we compiled several hypotheses that are part of the quantitative paradigm that can be further tested. The hypotheses in question are as follows.

1) There is an interactive correlation between Mastery of English Speaking Skills and Sense of Liking (preference).

2) There is an interactive correlation between Mastery of English Speaking Skills and Unpredictable learning (free-will learning).

3) There is an effect of Self-evaluation (informal evaluation) on the Mastery of English speaking skills.

\section{Discussion}

The thing that underlies the mastery of the informants' English speaking skills is the sense of liking to what they learn or we say preferent learning. Liking is not an inner driver because one's self-like is natural, both causal and non-causal, and static. What drives a person is motivation, both intrinsic and extrinsic. Maslow (1943), as the proponent for Motivation Theory, states that motivation is one of the determinants of a person's attitude and this is what distinguishes it from the Behavior Theory which is always motivated, biological, cultural, and situational; Alderman (2004); Gopang, Soomro, \& Bughio (2015); Durksen, Klassesn, \& Daniels (2017); Bukhary \& Bahanshal (2013); and Ferradás, Freire, Núñez, Piñeiro, \& Rosário, 2017). The informants' motivation towards English only emerged after having a sense of liking and an interest in them. Preference is included in the affective domain, as well as motivation, but this current research shows that it is not a motivational tendency that brings learners in achieving mastery of speaking skills in English but liking. Based on this, the results of the current study suggest considering the liking in learning as the affective domain, so that one's learning can truly become part of the existence of her/his learning.

On the other side, curiosity can be a factor in the emergence of a person's motivation and curiosity is based on liking. Someone who has a motivation, initially motivated by curiosity and curiosity arises because of a feeling of like. This means that when an element of liking does not exist, motivation can stop or changed at any time. It also shows at the same time that one's learning cannot be absolutely placed on motivation but preferably on a sense of liking or preference. Descartes in Corballis (2016) says that our body is not a machine that can move on its own but our body is a creature that has a soul in which there is a mind. When it is linked to motivation that has a starting point for physiological needs, it is certainly clear that motivation is not reliable or cannot be used as the main basis for one's learning (see Anselme, 2007; Green, 2016) and what should be the basis is a feeling of like that does have a starting point for psychological needs.

Concerning cognition, experts point out that cognition processes are included in neuroscience studies where the brain has a role in learning, (see Hermida, et al., 2015; and Komer \& Eliasmith, 2016) become central in the one's learning process. Cognition domain, according to them, has a huge impact on one's learning to gain knowledge and skills, increase attention, perception, consideration, the function of execution or decision making, and problem-solving (Tenison, Fincham, \& Anderson, 2016; Yan, 2010; Posner \& Rorhbart, 2014; Kotovsky \& Simon, 1990; and Anderson \& Fincham, 2014). Therefore, they suggest that learning should start from the process of cognition. Even for six (6) decades, from the 1950s to the 2000s, research on cognition related to learning was published publicly (Zhang, Sternberg, \& Rayner, 2012). This indicates that cognition has long been a barometer for the development of learning and makes it the first and foremost step in starting the learning, but our findings show different.

The findings in this current study indicate that the learning should be based on the affective domain; one's sense of liking on what and how s/he learns something, specifically in gaining the knowledge and skills s/he needs. During the discussion in the FGD activities, it was clear that the informants are people who are naturally lazy to learn. The question is that why can they show their speaking skills in English instead? Is it caused by intrinsic motivation or because of a sense of liking, or the role of cognition? Some so many people experience the same conditions but they can show their skills. This is certainly caused by a sense of liking or preference as a form of behavior so that the cognition process begins to run in the form of attitude and brings it at a conative level that is adequate to learn in an irregular (preferent) way. Motivation only occurs as a driver within someone when what one will do is something 
s/he likes, not because of something s/he thinks. In other words, learning should not be seen as something that respectively departs from one's cognition, then attitudes, then behaviors, and finally conative to improve psychomotor and interpersonal processes. It must be understood that everything is nothing constant in this life, and therefore, even the process of learning. It is necessary to apply various approaches, methods, and strategies that are considered to mediate each individual's learning processes. This certainly applies to every social variable, both measurable and immeasurable. Morgan (2004) said that scholars who apply the theory and practice of education are free to adopt what they consider most appropriate, under conditions of self-determination, and without binding commitments to pre-selected dogmas. At present, the field of education has expanded its theory and practice by modeling theories, principles, and practices from other disciplines. Besides, the theories and practices carried out at universities may not be compatible with the reality of teaching in schools because the teacher education curriculum is considered color-blind and does not have culturally responsive pedagogy (Schauer, 2018). Therefore, educators should conduct different activities from which they can learn a lot and must always have the need to learn to do their work as educators (Ping, Schellings, \& Beijaard, 2018). Educators can also use a variety of development standards but more in a mode that matches the level of resistance (Bourke, Ryan, \& Ould, 2018) with the aim to encourage and support the learning of their students in the classroom, especially language learning (Holdway \& Hitchcock, 2018) so that graduates can become global workers who are ready to be employed in the future (Minocha, Hristov, \& Leahy-Harland, 2018).

If it is associated with the most underlying thing in speaking skills mastery, it is clear that it is not the domain of cognition and motivation; even though motivation is included in the affective domain, but it is precisely a liking that is also one of the affective domains. The question then, is the Cognitive domain not needed in one's learning processes? Of course, the answer is it is needed. Then later, to what domain should the learners depend on learning foreign languages? The answer is that we should depend on the affective domain because this domain should be understood as central to the learning processes, both individually and collectively. Then, is the affective domain the most important thing among the three? The answer is certainly not, because the three domains are the integrated variables as a large series of the entire learning processes. However, it is better for the affective domain; liking, to be the most important basis for the learning. The aim is to mediate both other domains as well as psychomotor and interpersonal domain. Figure 8 below can be understood conceptually as the cycle of one's learning processes.

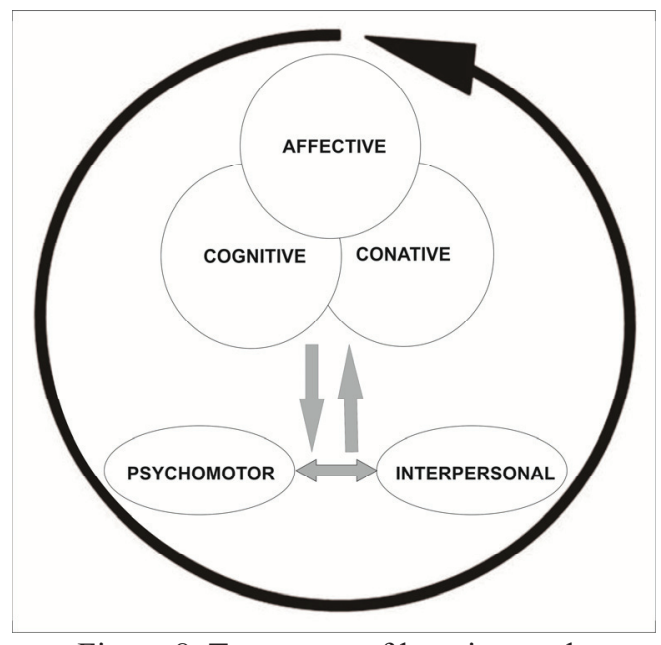

Figure 8. Taxonomy of learning cycle

Explanation.

a) Affective; changes in feelings (likes or dislikes; preferences), interests, enthusiasm, appreciation, values, motivation, attitudes, and development of adequate appreciation and adjustment (Bloom, Engelhart, Furst, Hill, \& Krathwohl, 1956).

b) Cognitive; involves knowledge and development of intellectual skills (Bloom, et al., 1956).

c) Conative; a form of social communication where someone tries to influence the mental and emotional state of others (Dennis, et al., 2013; Perner, Zauner, \& Sprung, 2005).

d) Psychomotor; manipulative or motorized areas oriented to body movements (Bloom, et al., 1956; Noorhidawati, Ghalebandi, \& Hajar, 2015) 
e) Interpersonal; inherently related and process-oriented, which is needed for communication and interaction with others by involving listening, body language, verbal language, and behavior and with the aim of recognizing emotions and resolving interpersonal conflicts (Duffy, et al., 2004; Bhana, 2014; Lolli, 2013; Calero, Mata, Bonete, Molinero, \& Gómez-Pérez, 2015).

Next, the informants' learning pattern for their English speaking skills is different from the general learning pattern. Besides being based on preferences, the informants' learning patterns are more likely to be irregular or based on their preference. That is, that the word irregular here means uncertain or in other words, according to their desires and actions (free will-whim). This pattern is unpredictable, which brings informants to the mastery of English speaking skills. The word preference refers to several things that are conceptually the basis for how the learning process is ideal for the informants. Here are some things that are meant.

1) Learning whenever and wherever; natural

2) Based on one's own desires or pleasures; more to own choice (preference; preferred)

3) Unexpected; suddenly; come and go; irregular; unplanned; flowing; do not have a certain way; informal (unpredictable)

4) Based on situation and curiosity (Situational and Curious - based)

5) No regulatory pressure or no discipline

The suggestion from Sert's (2006) research result showed that increasing awareness about autonomous learning and its benefits will be able to improve the self-regulation of the learners themselves which in turn can contribute to higher achievement and motivation. It is different from the learning in formal conditions which certainly has some academic regulations and becomes a routine process. Brandstatter (1994) said in his research finding that free time (pleasure activities) can provide better opportunities for satisfying social motives than when in a working situation (regulatory existence) and pleasure or desire is certainly one dimension of all linguistic exchange (Cameron \& Kulick, 2003). This is certainly one of the determinants of the success of one's speaking skills.

The Preferent learning, as labeled then, allows individuals to facilitate their learning, whether in a formal environment such as at the campus, school, and workplace, or in informal environments such as places where they are separated from binding regulations. Places like this can give learners the responsibility to improve their solution strategies and can benefit adaptive expertise (Carbonell, Stalmeijer, Könings, Segers, \& van Merriënboer, 2014). Adaptive expertise according to Carbonell et al. is a flexible condition that allows individuals to work at a high level in the face of task changes (topics of learning) and work methods (learning methods) and therefore, preferent learning is strongly recommended. The concept is shown in Figure 9.

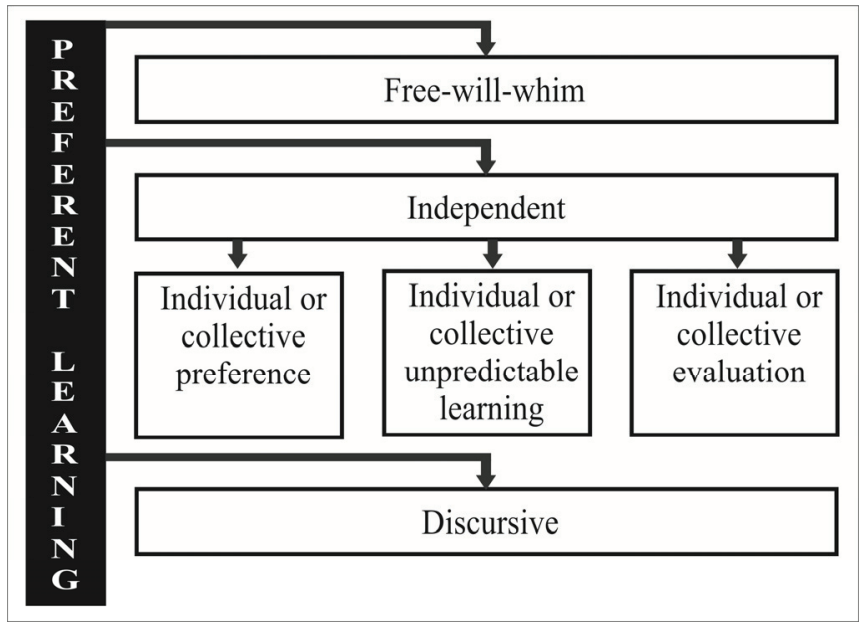

Figure 9. The concept of preferent learning theory

Ideally, after a learner has a sense of liking for what s/he learns, then s/he will naturally get into preference-based learning. When getting into the way of how a learner processes and acquires knowledge about the object s/he likes, then the Cognitive Style and Cognitive Learning Theory take on the role, this is because linguistic knowledge is not a guarantee in improving foreign language speaking skills. Let the learners be free, independent, and discursive in mediating their learning. This is very important to understand because of considering that everyone has a different 
language learning strategy and learning style that might create learning conditions for them in ways that can differ from individual to individual and considering socially the needs and desires of learners. Therefore, let the learners do it alone freely according to her/his desires and likes (Rezaee \& Farahian, 2012; Kumaravadivelu, 2006; Niu, Lu, \& You, 2018; and Chik \& Ho, 2017).

The mastery of English speaking skills in question here also involves an informal process of self-evaluation. The process of self-evaluation that is shown is very diverse to know and keep maintaining the mastery of their speaking skills in English which is of course done based on their desires and also unpattern. Self-evaluation does not mean doing a kind of formal test, but rather activities that can provide personal guidance about the mastery of skills that have been achieved so far. There are, at least, 8 ways of conducting self-evaluation in question are Self-imagery, Competitions, Interactions, Talk to Self, Watching English subtitle videos, Chatting, Practical teaching, and Long term evaluation. To continue to know the sustainability of mastering the English speaking skills, then it is necessary to evaluate ourselves because this includes quality assurance; determining what is good and what needs to be improved, quality increase; providing inspiration about how these things can be improved (van der Bij, Geijsel, \& ten Dam, 2016), and can be an important component in encouraging improvement in the provision of education services (McNamara \& O'Hara, 2008).

\section{Conclusion}

Based on the discussion, we conclude that in order to achieve the mastery of the English speaking skills, the learners need several things to know such as 1) a liking for English as a foreign language which is the basis of the affective domain in learning English as foreign language should be the basis for the learning, 2) irregular-based learning which is a free implementation in improving the mastery of speaking skills in English as a foreign language is ideal for any skills acquisition, 3) self-evaluations that are part of the implementation of the learning, as well as ways in which the learners know and keep maintaining the extent of the speaking skill mastery that has been obtained, should be considered in order to have the long term skills. Furthermore, the learning that has been prioritizing cognition and motivation need to be reconsidered and revisited because our substantive theory suggests the affective domain, in this case, the liking or preference which is the main basis in learning English speaking skills specifically and foreign languages generally.

\section{References}

Ahmadianzadeh, B., Seifoori, Z. \& Tamjid, N. H. (2018). Exploring EFL teachers' beliefs about and practices of learner autonomy across experience and licensure. Innovation in Language Learning and Teaching, 1-17. https://doi.org/ 10.1080/17501229.2018.1501694

Alderman, M. K. (2004). Motivation for Achievement - Possibilities for Teaching and Learning - Second Edition. London, UK: Lawrence Erlbaum Associates, Inc.

Anderson, J. R. \& Fincham, J. M. (2014). Extending problem-solving procedures through reflection. Cognitive Psychology, 74, 1-34. https://doi.org/10.1016/ j.cogpsych.2014.06.002

Anselme, P. (2007). Some conceptual problems with the classical theory of behaviour. Behavioural Processes, 75 , 259-275. http://dx.doi.org/10.1016/j.beproc.2007. 02.027

Strauss, A. L. \& Corbin, J. (1998). Basics of Qualitative Research - Techniques and Procedures for Developing Grounded Theory. London, UK: Sage Publications, Inc.

Arthur, L. \& Beaton, F. (2007). Adult foreign language learners: motivation, attitudes and behaviours. The Language Learning Journal, 21(1), 31-36. http://dx.doi.org/10.1080/09571730085200081

Ashton, K. (2017). Approaches to teaching in the multi-level language classroom. Innovation in Language Learning and Teaching, 1-16. http://dx.doi.org/ 10.1080/17501229.2017.1397158

Astika, G. (2014). Reflective teaching as alternative assessment in teacher education: A case study of pre-service teachers. TEFLIN Journal, 25(1), 16-31. http://dx.doi.org/10.15639/teflinjournal.v25i1/16-32

Bhana, V. M. (2014). Interpersonal skills development in Generation Y student nurses: A literature review. Nurse Education Today, 34(12), 1430-1434. https://doi.org/ 10.1016/j.nedt.2014.05.002

Bloom, B. S., Engelhart, M. D., Furst, E. J., Hill, W. H. \& Krathwohl, D. R. (1956). Taxonomy of Educational Objectives - The Classification of Educational Goals - Handbook I: The Cognitive Domain. New York, NY: David McKay Co Inc.

Bolhuis, S. \& Voeten, M. J. M. (2004). Teachers' conceptions of student learning and own learning. Teachers and Teaching: Theory and practice, 10(1), 77-98. http://dx.doi.org/10.1080/13540600320000170936 
Bourke, T., Ryan, M. \& Ould, P. (2018). How do teacher educators use professional standards in their practice? Teaching and Teacher Education, 75, 83-92, https://doi.org/10.1016/j.tate.2018.06.005

Brandstatter, H. (1994). Pleasure of Leisure-Pleasure of Work: Personality Makes the Difference. Personality and Individual Differences, 16(6), 931-946. https://doi.org/ 10.1016/0191-8869(94)90236-4

Brumen, M. (2011). The perception of and motivation for foreign language learning in pre-school. Early Child Development and Care, 181(6), 717-732. http://dx.doi.org/ 10.1080/03004430.2010.485313

Bukhary, S. A. \& Bahanshal, D. A. (2013). Motivation and Learning Strategies in a Foreign Language Classroom: A Look at Learners of Saudi Arabia. International Journal of Applied Linguistics \& English Literature, 2(5), 192-200. http://dx.doi.org/10.7575/aiac.ijalel.v.2n.5p.192

Calero, M. D., Mata, S., Bonete, S., Molinero, C. \& Gómez-Pérez, M. M. (2015). Relations between Learning Potential, Cognitive and Interpersonal Skills in Asperger Children. Learning and Individual Differences, 44, 53-60. https://doi.org/ 10.1016/j.lindif.2015.07.004

Cameron, D. \& Kulick, D. (2003). Introduction: Language and Desire in Theory and Practice. Language \& Communication, 23, 93-105. https://doi.org/ 10.1016/S0271-5309(02)00047-2

Carbonell, K. B., Stalmeijer, R. E., Könings, K. D., Segers, M. \& van Merriënboer, J. J. G. (2014). How Experts Deal with Novel Situations: A Review of Adaptive Expertise. Educational Research Review, 12, 14-29. https://doi.org/ 10.1016/j.edurev.2014.03.001

Chik, A. \& Ho, J. (2017). Learn a language for free: Recreational learning among adults. System, 69, $162-171$. http://dx.doi.org/10.1016/j.system.2017.07.017

Chuang, Szu-Fang. (2012). The relationship between cultural values and learning preference: the impact of acculturation experiences upon East Asians. International Journal of Training and Development, 16(1), 1-22. https://doi.org/10.1111/j.1468-2419.2011.00391.x

Conti, G. J. (2009). Development of a user-friendly instrument for identifying the learning strategy preferences of adults. Teaching and Teacher Education, 25, 887-896. http://dx.doi.org/10.1016\%2Fj.tate.2009.02.024

Corballis, M. C. (2016, Ed.). The Evolution of Language: Sharing Our Mental Lives. Journal of Neurolinguistics, 30, 1-13. https://doi.org/10.1016/j.jneuroling. 2016.06.003

Crawley, F. E. \& Shrum, J. W. (1997). Effects of learning structure condition on change in preference for science courses. Journal of Research in Science Teaching, 14(3), 257-262. https://doi.org/10.1002/tea.3660140311

Duffy, F. D., et al. (2004). Assessing competence in communication and interpersonal skills: The Kalamazoo II report. Academic Medicine, 79, 495-507. Retrieved 26 June, 2018 from https://journals.lww.com/academicmedicine/Fulltext/2004/06000/Assessing_ Competence_in_Communication_and.2.aspx

Durksen, T. L., Klassen, R. M \& Daniels, L. M. (2017). Motivation and Collaboration: The Keys to a Developmental Framework for Teachers' Professional Learning. Teaching and Teacher Education, 67, 53-66. https://doi.org/10.1016/j.tate.2017.05.011

Enkin, E. \& Correa, M. (2018). Evaluating Learner and Teacher Perceptions of Program Outcomes in the Foreign Language Major. Electronic Journal of Foreign Language Teaching, 15(1), 66-80.

Ferradás, M. del Mar, Freire, C., Núñez, J. C., Piñeiro, I. \& Rosário, P. (2017). Motivational Profiles in University Students. Its Relationship with Self-Handicapping and Defensive Pessimism Strategies. Learning and Individual Differences, 56, 128-135. https://doi.org/10.1016/j.lindif.2016.10.018

Folkestad, G. (2006). Formal and informal learning situations or practices vs formal and informal ways of learning. British Journal of Music Education, 23(2), 135 - 145. https://doi.org/10.1017/S0265051706006887

Frank, A. G., Dalenogare, L. S. \& Ayala, N. F. (2019). Industry 4.0 technologies: implementation patterns in manufacturing companies. International Journal of Production Economics, 210, 15-26. https://doi.org/10.1016/j.ijpe.2019.01.004

Funk, H. (2012). Four Models of Language Learning and Acquisition and Their Methodological Implications for Textbook Design. Electronic Journal of Foreign Language Teaching, 9(1), 298-311.

Gearing, N. \& Roger, P. (2018). Ebbs and Flows: A Longitudinal Study of an English Language Instructor's Motivation to Learn Korean. Journal of Language, Identity \& Education, 1-14, 
https://doi.org/10.1080/15348458.2018.1465343

Glaser, B. G. \& Strauss, A. L. (1999). The Discovery of Grounded Theory - Strategies for Qualitative Research. USA: Aldine Transaction.

Gopang, I. B., Soomro, A. F. \& Bughio, F. A. (2015). Increasing Motivation at University Level: A Paradigm of Action Research. Journal of Language Teaching and Research, 6(1), 140-146. http://dx.doi.org/10.17507/j1tr.0601.17

Green, K. (2016). The Human Brain Does Not Need High Levels of Motivation to Learn a Foreign Language: Motivation Has Had its Day. Advances in Language and Literary Studies, 7(5), 70-77. http://dx.doi.org/10.7575/aiac.alls.v.7n.5p.70

Haleem, A. \& Javaid, M. (2018). Industry 5.0 and its applications in orthopaedics. Journal of Clinical Orthopaedics and Trauma. https://doi.org/10.1016/j.jcot.2018.12.010

Haworth, P., Mcgee, A. \& Macintyre, L. K. (2015). Building A Whole School Approach and Teacher Efficacy with English Language Learners. Teachers and Teaching: Theory And Practice, 21(2), $164-177$. http://dx.doi.org/10.1080/ 13540602.2014.928131

Hermida, M. J., Segretin, M. S., Prats, L. M., Fracchia, C. S., Colombo, J. A. \& Lipina, S. J. (2015). Cognitive neuroscience, developmental psychology, and education: Interdisciplinary development of an intervention for low socioeconomic status kindergarten children. Trends in Neuroscience and Education, 4(1-2), 15-25. https://doi.org/10.1016/j.tine.2015.03.003

Holdway, J. \& Hitchcock, C. H. (2018). Exploring ideological becoming in professional development for teachers of multilingual learners: Perspectives on translanguaging in the classroom. Teaching and Teacher Education, 75, 60-70. https://doi.org/ 10.1016/j.tate.2018.05.015

Hu, Y., Gao, H., Wofford, M. M. \& Violat, C. (2017). A Longitudinal Study in Learning Preferences and Academic Performance in First Year Medical School. Anatomical Science Education, https://doi.org/10.1002/ase.1757

Karimi, M. N. \& Zade, S. S. H. (2018). Teachers' use of motivational strategies: effects of a motivation-oriented professional development course. Innovation in Language Learning and Teaching, 1-11. https://doi.org/10.1080/17501229.2017.1422255

Kiziltepe, Z. (2008). Motivation and demotivation of university teachers. Teachers and Teaching: Theory and practice, 14(5-6), 515-530. http://dx.doi.org/10.1080/ 13540600802571361

Komer, B \& Eliasmith, C. (2016). A unified theoretical approach for biological cognition and learning. Current Opinion in Behavioral Sciences, 11, 14-20. https://doi.org/10.1016/j.cobeha.2016.03.006

Kotovsky, K. \& Simon, H. A. (1990). What makes some problems really hard: Explorations in the problem space of difficulty. Cognitive Psychology, 22(2), 143-183. https://doi.org/10.1016/0010-0285(90)90014-U

Kumaravadivelu, B. (2006). Understanding Language Teaching - From Method to Post method. London, UK:Lawrence Erlbaum Associates, Inc.

Lasagabaster, D. (2011). English achievement and student motivation in CLIL and EFL settings. Innovation in Language Learning and Teaching, 5(1), 3-18. http://dx.doi.org/10.1080/17501229.2010.519030

Liyanage, I., Bartlett, B., Walker, T. \& Guo, X. (2014). Assessment policies, curricular directives, and teacher agency: quandaries of EFL teachers in Inner Mongolia. Innovation in Language Learning and Teaching, 1-14. http://dx.doi.org/ 10.1080/17501229.2014.915846

Lolli, J. C. (2013). Interpersonal communication skills and the young hospitality leader: Are they prepared?. International Journal of Hospitality Management, 32, 295-298. https://doi.org/10.1016/j.ijhm.2012.02.010

Maslow, A. H. A. (1943). Theory of Human Motivation. Psychological Review, 50(4), 370-396. http://dx.doi.org/10.1037/h0054346

McNamara, G. \& O'Hara, J. (2008). The Importance of the Concept of Self-Evaluation in the Changing Landscape of Education Policy. Studies in Educational Evaluation, 34, $173-179$. https://doi.org/10.1016/j.stueduc.2008.08.001

Meredith, J. E., Fortner, R. W. \& Mullins, G. W. (1997). Model of Affective Learning for Nonformal Science Education Facilities. Journal of Research in Science Teaching, 34(8), 805-818.

Met, M. \& Byram, M. (1999). Standards for foreign language learning and the teaching of culture. The Language 
Learning Journal, 19/1, 61-68. http://dx.doi.org/ 10.1080/09571739985200121

Minocha, S., Hristov, D. \& Leahy-Harland, S. (2018). Re: Developing a future-ready global workforce: A case study from a leading UK university. The International Journal of Management Education, 162, $245-255$. https://doi.org/10.1016/j.ijme.2018. 03.002

Morgan, H. (2004). Real Learning - A Bridge to Cognitive Neuroscience. Maryland, UK: The Rowman \& Littlefield Publishing Group, Inc.

Muhuri, P. K., Shukla, A. K. \& Abraham, A. (2019). Industry 4.0: A bibliometric analysis and detailed overview. Engineering Applications of Artificial Intelligence, 78, 218-235. https://doi.org/10.1016/j.engappai.2018.11.007

Niu, R., Lu, K. \& You, X. (2018). Oral language learning in a foreign language context: Constrained or constructed? A sociocultural perspective. System, 74, 38-49. https://doi.org/10.1016/j.system.2018.02.006

Noorhidawati, A., Ghalebandi, S. G. \& Hajar, R. S. (2015). How Do Young Children Engage with Mobile Apps? Cognitive, Psychomotor, and Affective Perspective. Computers \& Education, 87, 385-395. https://doi.org/10.1016/j.compedu. 2015.07.005

Perner, J., Zauner, P., Sprung, M. (2005, Eds.) What Does “That” Have to Do with Point of View? Conflicting Desires and "Want” in German. In Astington, J. W. \& Baird, J. A. Why Language Matters for Theory of Mind. New York, NY: Oxford University Press.

Ping, C., Schellings, G. \& Beijaard, D. (2018). Teacher educators' professional learning: A literature review. Teaching and Teacher Education, 75, 93-104, https://doi.org/10.1016/j.tate.2018.06.003

Posner, M. I. \& Rothbart, M. K. (2014). Attention to learning of school subjects. Trends in Neuroscience and Education, 3(1), 14-17. https://doi.org/10.1016/ j.tine.2014.02.003

Rauch, E., Linder, C. \& Dallasega, P. (2019). Anthropocentric perspective of production before and within Industry 4.0. Computers \& Industrial Engineering. https://doi.org/10.1016/j.cie.2019.01.018

Rezaee, M. \& Farahian, M. (2012). The case study of a field-independent English language learner. Procedia Social and Behavioral Sciences, 47, 114-119. https://doi.org/10.1016/j.sbspro.2012.06.623

Rienties, B. \& Kinchin, I. (2014). Understanding (in) formal learning in an academic development programme: A social network perspective. Teaching and Teacher Education, 39, 123-135. http://dx.doi.org/10.1016/j.tate.2014.01.004

Ruesch, A., Bown, J. \& Dewey, D. P. (2012). Student and teacher perceptions of motivational strategies in the foreign language classroom. Innovation in Language Learning and Teaching, 6(1), 15-27. http://dx.doi.org/10.1080/17501229.2011. 562510

Sachsenmeier, P. (2016). Industry 5.0-The Relevance and Implications of Bionics and Synthetic Biology. Engineering, 2(2), 225-229. https://doi.org/10.1016/J.ENG.2016.02.015

Schauer, M. M. (2018). "Vygotsky for the Hood": Connecting teacher prior life experiences and university teacher preparation curriculums for service in urban schools. Teaching and Teacher Education, 74, 1-9. https://doi.org/10.1016/ j.tate.2018.04.009

Sert, N. (2006). EFL Student Teachers' Learning Autonomy. The Asian EFL Journal Quarterly, 8(2), $180-201$.

Tenison, C., Fincham, J. M. \& Anderson, J. R. (2016). Phases of learning: How skill acquisition impacts cognitive processing. Cognitive Psychology, 87, 1-28. https://doi.org/10.1016/j.cogpsych.2016.03.001

Widiastuti, I. A. M. S. (2018). EFL Teachers' Beliefs and Practices of Formative Assessment to Promote Active Learning. The Asian EFL Journal, 20(5), 96-112. Retrieved from https:/www.asian-efl-journal.com/11022/teaching-articles/2018-teaching-articles/volume-20-issue-5-2018/\#squ elch-taas-tab-content-0-1

Yan, J. H. (2010). Cognitive styles affect choice response time and accuracy. Personality and Individual Differences, 48, 747-751. https://doi.org/10.1016/ j.paid.2010.01.021

Yang, H. (2017). Complexity in classroom foreign language learning motivation: a practitioner perspective from Japan. International Journal of Bilingual Education and Bilingualism, 1-4. http://dx.doi.org/10.1080/13670050.2017.1291075

Zhang, L. F., Sternberg, R. J. \& Rayner, S. (2012, Eds.). Handbook of Intellectual Styles - Preferences in Cognition, Learning, and Thinking. New York, NY: Springer Publishing Company, LLC. 